\title{
Simulium spp. Control Program in Rio Grande do Sul, Brazil
}

\section{Lucia Beatriz LF Mardini/ ${ }^{+}$, Maria Amélia N Torres, Geraldo Lopes da Silveira*, Ana Maria V Atz**}

\begin{abstract}
Coordenação de Política de Controle de Zoonoses e Vetores, Secretaria da Saúde, Av. Borges de Medeiros 72760 andar, 90020-025 Porto Alegre, RS, Brasil *Departamento de Hidráulica e Saneamento, Centro de Tecnologia, Universidade Federal de Santa Maria, Santa Maria, RS, Brasil ** Emater, Porto Alegre, RS, Brasil

Insects of the Simuliidae family have been the object of control in Rio Grande do Sul since the 70s. Their constant attacks became a social-economical problem as well as a problem of Public Health, with serious consequences to men and to the economy of the areas in which the insects develop. At first, the control was done with a chemical larvicide Themephos ABATE 500 E, but an imperfect measuring of outflow to determine the quantity of the product made Simulium spp. resistant to it. From 1983 on, following a study of a new method for the outflow measuring, we started to use a biological larvicide Bacillus thuringiensis serovar israelensis based. The biological control uses the new method in $36.4 \%$ of the state area, assisting about 3,500,000 inhabitants.
\end{abstract}

Key words: Simulium spp. - biological control - Bacillus turingiensis serovar israelensis - Rio Grande do Sul Brazil

The hematophagic insects of the Simuliidae family (Diptera - Nematocera) are important in Brazil, where there are 81 species (Py-Daniel 1988). In Rio Grande do Sul (RS), 30 species have already been identified. Some of them have been reported as having attacked men and animals alike for decades (Souza 1984, Strieder \& Corseuil 1992), causing damage to agriculture, cattle farming, and tourism, next to relevant aftermaths in public health.

From 1976 on, the Secretary for Health started to take action in the control of Simulium spp., first by deploying the organophosphorous chemical larvicide, Themophos ABATE $500 \mathrm{E}$. Throughout these controlling tasks, research carried out by the Coordination for the Political Control of Zoonoses and Vectors of the Secretary of Helth (CPCZV) indicated that the species under control, $S$. (Chirostilbia) pertinax, was not susceptible to the concentrations being applied, what suggested that resistance had been developed by product misuse due to improper measuring of outflow (Ruas Neto 1984a). Research conducted by Andrade et al. (1987) in São Paulo indicated that the efficacy of the product over $S$. $(C$.) pertinax larvae was unsatisfactory.

${ }^{+}$Corresponding author. Fax: +55-51-224.5659

E-mail: luciabeatriz@terra.com.br

Received 7 August 2000

Accepted 4 September 2000
In 1982 research was started on new methodologies of integrated control of Simulium spp. (Ruas Neto 1984b, Ruas Neto et al. 1985) and on effective ways of measuring outflow, meeting the specificities of the river basins in RS. The new methodology was developed by Silveira (1985) and implanted from 1983 on, making use of modified "Parshal" fixed outflow meter (Alfaro 1974) in the application of Bacillus thuringiensis serovar israelensis H14 de Barjac 1978 based formulations.

This methodology took into account the environmental characteristics in RS, where there are small and medium-size river basins with variable rainfall and where flood drain occurs within minutes or few hours. The device consists of fixed structures called outflow meters, or "Parshal" shallow gutters, built in the main streak of every basin (Fig. 1). This makes it possible to check the outflow on this assembled device and, in the sequence, to calculate dosage, concentration and delivery of the product. This is done according to charts that apply to the size of the outflow meters. There are five sizes that meet the different draining conditions of the river basins where the larvicide product will be used. Presently, the Control Program comprehends 170 municipalities, out of which 122 have 223 built-in fixed outflow meters. The remaining have already been surveyed as to entomology, epidemiology and hydrology conditions so that the fixed outflow meters can be built (Fig. 2).

Simulium spp. control in RS aims to reduce associated morbidity by means of its population control. This is carried out through biological control 
with B. thuringiensis var. israelensis, using methodology attentive to our specific environmental conditions. The program also aims to raise awareness, to foster environment recovery, and to give assistance to the population victimized by the insects. It is under the coordination, normatization, and technical assistance of the CPCZV, with the support of the municipal and regional bureaus of Emater, RS. The municipal governments are in charge of the execution and the control of the program.
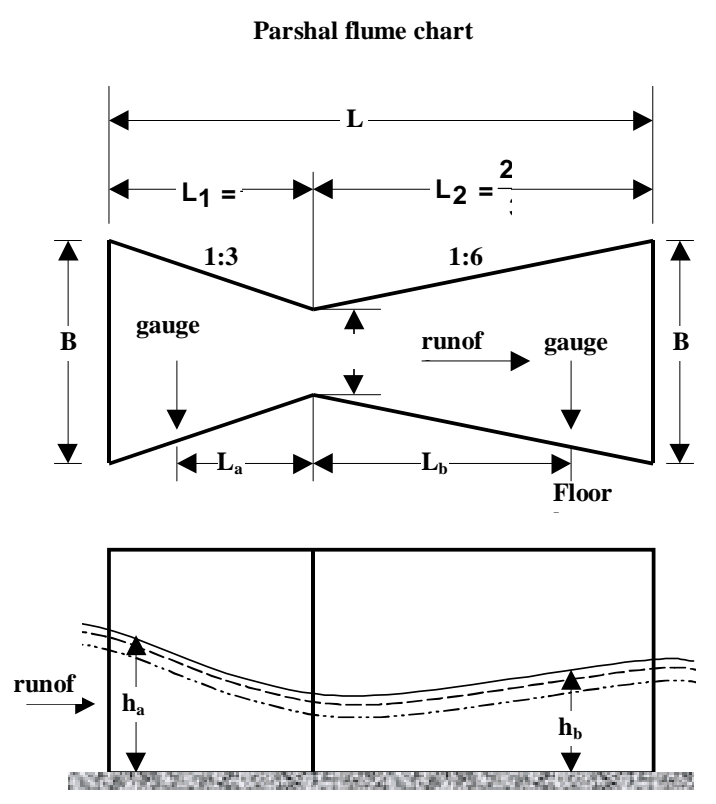

Cross

$B=W+\frac{L}{4,5} \quad, \quad L_{a}=\frac{2}{9} L, L$

Fig. 1: "Modified Parshal Gutter" outflow meter

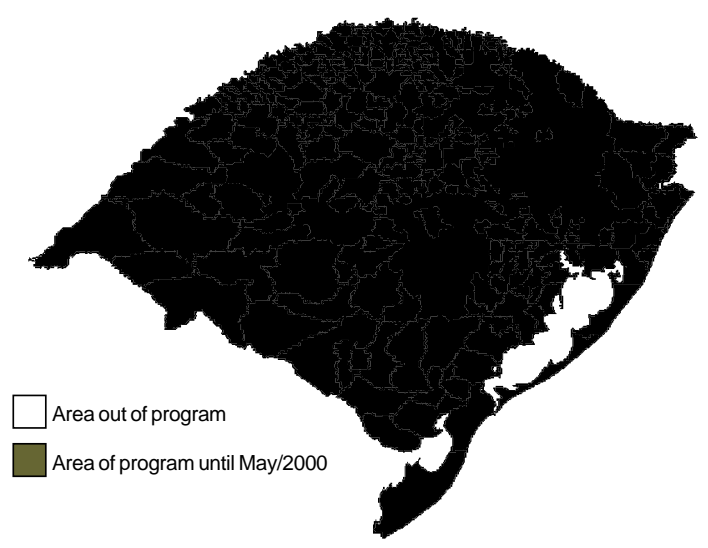

Fig. 2: area under Simulium spp. Control State Program in Rio Grande do Sul
The hydrologic study of the built-in fixed outflow meters, their effectiveness and other forms of outflow measuring are under permanent assessment through the integrated association with the Hydraulics and Sanitation Department of the Santa Maria Federal University (Silveira 1997, Mardini et al. 1998, Mardini \& Souza 1998, Silveira \& Tucci 1998, Silveira et al. 1998).

\section{MATERIALS AND METHODS}

Firstly, the entomological survey of immature and adult forms of Simulium spp., the epidemiological survey of the attacks to people in the area, and the study of the river basin are carried out by the CPCZV team. The site for the construction of the modified "Parshal" fixed outflow meter is determined taking into account its volume of water and its accessibility conditions.

The assessment of the outflows along the waterway, which is fundamental to calculate the concentrations of larvicide dosage, is made by using a micro screw current meter or, as in Amrine (1983), with a float system (ping-pong ball with 25 $\mathrm{ml}$ of water as ballast). The resulting measures served as the basis for the projects of five sizes of the modified "Parshal" fixed outflow meters: 10x90; 30x90; 40x180; 60x180; 100x270 (cm).

The fixed outflow meter in each river basin to be controlled made of masonry or concrete, makes it possible to correctly calculate the outflow of the waterway and to establish correlations with the other waterways in the same basin.

\section{RESULTS}

B. thuringiensis var. israelensis based formulations are widely used for controlling purposes in many countries (Undeen \& Colbo 1980, Lacey 1982, 1998, Lacey \& Undeen 1984, OCP/WHO 1994, Molyneux 1995, Hougard 1998). In Brazil, RS was the state to pioneer biological control, and its use has proved to be efficient in the control of Simulium spp. larvae without interfering in the aquatic organisms associated to the insects' habitat (Mardini 1988, Mardini et al. 1993, 1998, 1999, Souza et al. 1994).

It is the Executive of the municipalities' responsibility to do this control referring to the Technical and Operational Norms of the Secretary for Health, which describes the outflow measuring method to use the biological larvicide.

The efficacy of the biologic larvicide resulting from the correct outflow measuring has been reported in many papers (Ruas Neto et al. 1985, Souza et al. 1994, Mardini et al. 1998, 1999). Adaptations to this method have been studied and should determine that less fixed outflow meters be built, as suggested by the work developed in association 
with the Hydraulics and Sanitation Department of the Federal University of Santa Maria (UFSM/ Fapergs 1992, Souza et al. 1994, Silveira 1998).

From 1983 to April 2000, 223 fixed outflow meters were built, and 94 are still to be built (Table I). In all 170 municipalities requested to join the program from 1983 to May 2000, what corresponds to $36.4 \%$ of the municipalities in the state and nearly 3,500,000 people (Table II).

\section{TABLE I}

Number of fixed outflow meters projected and built

\begin{tabular}{cc}
\hline $\begin{array}{c}\text { Fixed outflow meters } \\
\text { projected }\end{array}$ & $\begin{array}{c}\text { Fixed outflow } \\
\text { meters built }\end{array}$ \\
\hline $94^{a}$ & $223^{b}$
\end{tabular}

$\bar{a}$ : number of total outflow projected; $b$ : number of total outflow meters built since 1983 .

\section{TABLE II}

Number of municipalities in Rio Grande do Sul per year of joining the Control Program from 1983 to May 2000

\begin{tabular}{|c|c|c|}
\hline Year & No. of municipalities & $\%$ of municipalities \\
\hline 1983 & 3 & 0.9 \\
\hline 1988 & 22 & 6.6 \\
\hline 1994 & 68 & 15.6 \\
\hline 1996 & 107 & 24.5 \\
\hline 1997 & 116 & 26.5 \\
\hline 1998 & 135 & 31.6 \\
\hline 2000 & $170^{a}$ & 36.4 \\
\hline
\end{tabular}

a: until May 2000

\section{DISCUSSION}

The effectiveness of biological control, given the environmental specificities at play, requires a correct methodology of measuring outflow. The successful experience in using Simulium spp. biological control in RS leads to deem the method of fixed "Parshal" outflow meters adequate to small rural river basins. The integrated use of control methods, environmental recovery and preservation, and continued education of communities are fundamental to the success of Simulium spp. control programs in whatever region to be considered.

\section{ACKNOWLEDGMENTS}

To the officials in the Coordination for the Political Control of Zoonoses and Vectors, Jorge Wilson, Valter Jándir Vasconcelos, Pedro Aquino, and Nilton Lopes, in charge of the implantation of this program in the municipalities.

\section{REFERENCES}

Alfaro JF 1974. Medidas de água en canales por medio del aforador "sin cuello". Ann I Simp Intern Irrig, Porto Alegre, RS, p. 459-529.

Amrine Jr JW 1983. Measuring stream discharge and calculating treatment of rates of Bacillus thuringiensis (H14) for black fly control. Mosq News 43: 17-21.

Andrade CFS, Moreira LFDP, Castelo Branco Jr A 1987. Resistência de populações de 3 espécies de Simuliidae ao inseticida Temephos. Cong Bras Entomol, Campinas, p. 406.

Hougard JM 1998. The use of Bti in the onchocerciasis control programme in West Africa, VI Simp Control Biol, Rio de Janeiro, p. 38-40.

Lacey LA 1982. Large river treatment with Bacillus thuringiensis $(\mathrm{H}-14)$ for the control of Simulium damnosum. The Onchocerciasis Control Program. Tropenmed Parasit 33: 97-101.

Lacey LA 1998. Development of entomopathogens as microbial control agents of mosquitoes and black flies: 30 years of progress. Ann VI Simp Cont Biol, Rio de Janeiro, p. 23-28.

Lacey LA, Undeen AH 1984. Concentration and application time on the efficacy of Bacillus thuringiensis (H-14) against blackfly (Diptera: Simuliidae) larvae under natural conditions. J Economic Entomol 77: 412-418.

Mardini LBLF 1988. Ocorrência de larvas de simulídeos e outros insetos no conteúdo estomacal das espécies de peixes capturados em uma área piloto do Programa Estadual de Controle do Rio Grande do Sul. Ann II Sem Nac An Sinant III Reun Bras Simul, Porto Alegre, p. 71-72.

Mardini LBLF, Souza MAT 1998. Programa Estadual de Controle do Simulium spp. no Rio Grande do Sul - A importância do método de vazão. Ann III Sem Nac Zoon Anim Peçonh, Guarapari, p. 112.

Mardini LBLF, Souza MAT, Magni-Darwich S, Barbosa UC 1993. Programa estadual de controle do simulídeo no Rio Grande do Sul, Brasil. Fauna aquática de arroios tratados e não tratados com inseticidas. Ann IV Cong Cubano Microb Parasit I Cong Med Trop, Havana, Cuba, p. 140.

Mardini LBLF, Souza MAT, Rabinovitch L, Alves RS, Silva CMB 1999. Fields studies with the bacterial larvicide INPALBAC for Simulium spp. Control in Rio Grande do Sul, Brazil. Mem Inst Oswaldo Cruz 94: 679-681.

Mardini LBLF, Souza MA, Silveira GL, Atz AMV 1998. Medidores fixos de vazão em pequenas bacias rurais para utilização de larvicida biológico no controle de Simulium spp. (Diptera-Simuliidae) no Rio Grande do Sul, Brasil. I For Geo-Bio-Hidrol, Curitiba, p. 184-189.

Molyneux DH 1995. Onchocerciasis control in West Africa: current status future of the Onchocerciasis Control Programme. Parasitol Today 11: 399-402.

OCP/WHO 1994. Onchocerciasis Control Programme 1974-1994, 25 pp.

Py-Daniel V 1988. Simuliidae no Brasil. Ann II Sem Nac Anim Sinant, Porto Alegre, p. 2.

Ruas Neto AL 1984a. Avaliação do uso de temephos 
para o controle de culicídeos e simulídeos no Rio Grande do Sul. B Saúde 11: 27-31.

Ruas Neto AL 1984b. Bacillus thuringiensis var. israelensis, como alternativa no controle de simulídeos no Rio Grande do Sul.1. Susceptibilidade a campo. B Saúde 11: 21-26.

Ruas Neto AL, Silveira SM 1989. Uso de inseticidas bacterianos para o controle de culicídeos e simulídeos no Rio Grande do Sul. Mem Inst Oswaldo Cruz 84: 39-45.

Ruas Neto A, Souza, MAT, Severino S, Melo JLB, Silveira SM, Fontes NDF 1985. Controle integrado do Simulium (Chirostilbia) pertinax Kollar, 1822 Utilização de Bacillus thuringiensis var. israelensis no Rio Grande do Sul. B Saúde 12: 17-20.

Silveira RL 1985. Projeto Simulídeo - IPH. Relatório parcial $\mathrm{N}^{\circ} 7$. Instituto de Pesquisas Hidráulicas da UFRGS, Porto Alegre, RS.

Silveira GL 1997. Quantificação de Vazão em Pequenas Bacias com Carência de Dados Fluviométricos, $\mathrm{PhD}$ Thesis, Programa de Pós-graduação em Engenharia dos Recursos Hídricos e Saneamento Ambiental do IPH/UFRGS, Porto Alegre, $172 \mathrm{pp}$.

Silveira GL,Tucci CEM 1998. Monitoramento em pequenas bacias para a estimativa de disponibilidade hídrica. Rev Bras Rec Hídricos 3: 97-110.

Silveira GL, Tucci CEM, Silveira ALL 1998. Quantificação de vazão em pequenas bacias sem dados. Rev Bras Rec Hídricos 3: 111-131.

Souza MA 1984. Atendimento médico por picadas de simulídeos, Porto Alegre. B Saúde 11: 8-11.

Souza MAT, Mardini LBLF, Gomes EC, Silveira GL 1994. Evolução do controle de simulideos através do Bacillus thuringiensis var. israelensis no Rio Grande do Sul. I Sem - Qual Águas Cont no MERCOSUL, p. 261-278.

Strieder MN, Corseuil E 1992. Atividades de hematofagia em Simuliidae (Diptera, Nematocera) na Picada Verão, Sapiranga, RS, Brasil. Acta Biol Leopoldensia 14: 75-97.

UFSM/FAPERGS 1992. Estudos hidrológicos para dosificação do Bacillus thuringiensis var. israelensis no combate ao simulídeo. Relatório parcial da pesquisa, $7 \mathrm{pp}$.

Undeen SH, Colbo MH 1980. The efficacy of Bacillus thuringiensis var. israelensis against blackfly larval (Diptera, Simuliidae) in their natural habitat. Mosq News 40: 181-184. 